\title{
Self-policing backed for research on humans
}

\section{Colin Macilwain, Washington}

The presidents of America's top research universities have come up with a set of proposals for tightening up the policing of research on human subjects.

The plan, published in Washington last week by the Association of American Universities (AAU), addresses mounting public anxiety about the safety of individuals taking part in such trials. Levels of concern have been high since the death last September of teenager Jesse Gelsinger, who died while undergoing gene-therapy trials at the University of Pennsylvania (see Nature 401,517; 1999).

"University presidents, such as myself, have to be more involved" in the supervision of human-subject research, says Dennis Smith, president of the University of Nebraska at Lincoln and co-chair of the AAU task force behind the plan. University presidents would welcome greater involvement in regulating research, adds Nils Hasselmo, president of the AAU, as the problems that result from lax regulation "end up on the presidents' desks".

The AAU, which represents the presidents of 59 top US and two Canadian research institutions, says its proposals would require considerable investment from its members. But its plan goes further than the regulations being implemented at the universities by the federal government.

The scheme would involve university presidents more deeply in monitoring clinical research. It would commit resources for better training of the researchers involved in human-subject research, and strengthen the institutional review boards (IRBs) that review clinical trials. "Money needs to be made available to give the IRBs sufficient resources to do the job," says Smith. "Another priority is to put more members of the public on IRBs."

The AAU's plan would also establish a system of 'voluntary accreditation', similar to that in effect for animal research, to reassure the public that research subjects are protected.

Hasselmo says that most university presidents support the legislation proposed by Representative Diana DeGette (Democrat, Colorado), which aims to strengthen the fragmented IRB network. The Association of American Medical Colleges (AAMC), repre-

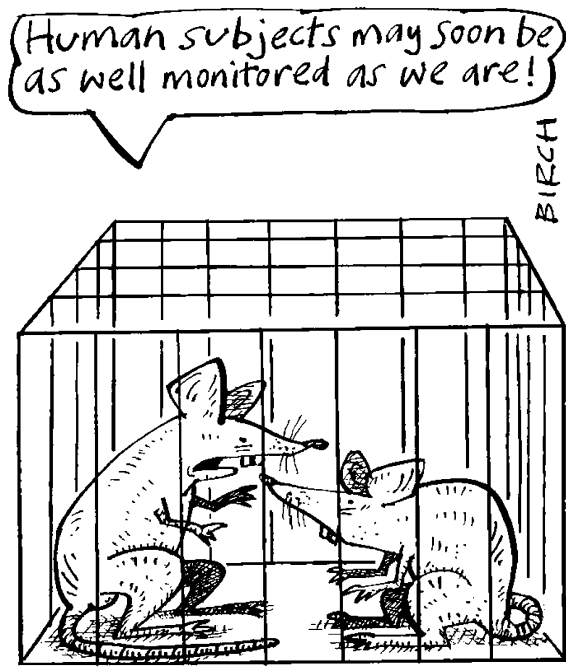

senting the medical schools, has already endorsed the bill. The AAU has yet to adopt a formal position.

Some patient advocacy groups say that self-regulation of human-subject research has already failed, most notably in Gelsinger's case. They want independent, external regulation, pointing out that neither the AAU nor the legislation before Congress provide this.

Under both DeGette's bill and the AAU's plan, institutions conducting human-subject research would register voluntarily for accreditation with an independent body. The Boston-based non-profit organization Public Responsibility in Medicine and Research (PRIM\&R), which trains researchers and IRB members in human-subject protection, is preparing itself to fulfil this role, with the blessing of the AAMC and the AAU.

But Vera Sharav, president of Citizens for Responsible Care and Research, a New Yorkbased group advocating research subjects' rights, dismisses PRIM\&R as "an organization that represents the IRBs". She ridicules the AAU for proposing "independent selfmonitoring" at institutions. "Self-monitoring cannot be independent," she says. The AAU says the phrase refers to monitoring by the universities, independent of the IRBs, and that the accreditation system will provide additional, external monitoring.

A spokesman for DeGette says the bill has strong bipartisan support, and that it should hopefully be the subject of Congressional hearings before the end of the month.

\section{Austrian physics meeting passes without boycott}

\section{Quirin Schiermeier}

The high attendance at a physics meeting in Vienna last week - as well as the continued refereeing of Austrian research proposals by foreign scientists - suggests that fears of a boycott of Austria by the international scientific community may be unfounded.

But several hundred of those attending the seventh European Particle Accelerator Conference (EPAC) signed a letter to Austrian Chancellor Wolfgang Schüssel saying that their participation "should not be misconstrued as an indication of support for the present Austrian government".

Earlier this year, the US Department of Energy and the American Physical Society discussed a possible boycott in response to the inclusion in Austria's coalition government of the far-right Austrian Freedom Party.

Although the United States stepped back from an official boycott, some laboratories, such as the Brookhaven National
Laboratory, and many scientists both inside and outside the United States pledged to boycott the meeting, leading to fears that it could face serious economic difficulties.

But many apparently changed their minds at the last minute, possibly in response to calls from Austria's science agencies for support from the international scientific community (see Nature 403, 691; 2000). The EPAC was attended by 750 physicists, including 103 from the United States. Although $10 \%$ fewer than initially expected, this was more than attended the 1998 EPAC in Stockholm.

The letter to the Austrian government was drafted by scientists in the United States and at CERN, the European Laboratory for Particle Physics. Signatories included Andrew Sessler, former president of the American Physical Society, and Yuri Orlov, the honorary chairman of the International Helsinki Federation for Human Rights.

Representatives of the Austrian government were excluded from the meeting on the advice of Steve Myers of CERN, chairman of EPAC's international organizing committee.

"I personally think that at least the Austrian science minister, Elisabeth Gehrer, should have been invited to give a message of greeting," says Meinhard Regler, vice-director of the Vienna-based Institute for High Energy Physics and chairman of the local organizing committee. "But I agree that the presence of an Austrian minister could have easily led to embarrassing situations."

Arnold Schmidt, president of the Austrian Science Fund, Austria's main research-funding agency, says the political situation has not caused serious problems for Austrian scientists. Responses to only four out of 2,500 grant applications sent to referees outside Austria mentioned the Europe-wide restrictions of diplomatic relations with Austria, and there has been no significant reduction in the return rate of reviews, he says. 